\title{
Animal World and Living Behaviour - Managerial Implications
}

\author{
K. V. M. Varambally ${ }^{1}$ \& P. S. Aithal ${ }^{2}$ \\ ${ }^{1}$ Research Professor, College of Management \& Commerce, Srinivas University, \\ Mangalore- 575 001, India \\ E-mail: kvmvarampally@ gmail.com \\ ${ }^{2}$ Vice Chancellor, Srinivas University, Mangalore - 575001 \\ Orcid ID : 0000-0002-4691-8736, Email: psaithal@gamil.com
}

Area/Section: Management Science.

Type of the Paper: Research Paper.

Type of Review: Peer Reviewed as per $|\mathrm{C}| \mathrm{O}|\mathrm{P}| \mathrm{E} \mid$ guidance.

Indexed in: OpenAIRE.

DOI: http://doi.org/10.5281/zenodo.3564958.

Google Scholar Citation: IJMTS.

\section{How to Cite this Paper:}

Varambally, K. V. M., \& Aithal, P. S. (2019). Animal World and Living Behaviour - Managerial Implications. International Journal of Management, Technology, and Social Sciences (IJMTS), 4(2), 104-109. DOI: http://doi.org/10.5281/zenodo.3564958.

International Journal of Management, Technology, and Social Sciences (IJMTS) A Refereed International Journal of Srinivas University, India.

IFSIJ Journal Impact Factor for $2018=4.764$

(C) With Authors.

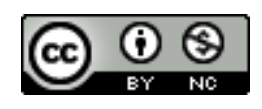

This work is licensed under a Creative Commons Attribution-Non Commercial 4.0 International License subject to proper citation to the publication source of the work.

Disclaimer: The scholarly papers as reviewed and published by the Srinivas Publications (S.P.), India are the views and opinions of their respective authors and are not the views or opinions of the SP. The SP disclaims of any harm or loss caused due to the published content to any party. 


\title{
Animal World and Living Behaviour - Managerial Implications
}

\author{
K. V. M. Varambally ${ }^{1} \&$ P. S. Aithal ${ }^{2}$ \\ ${ }^{1}$ Research Professor, College of Management \& Commerce, Srinivas University, \\ Mangalore- 575 001, India \\ E-mail: kvmvarampally@gmail.com \\ ${ }^{2}$ Vice Chancellor, Srinivas University, Mangalore - 575001, India \\ Email:psaithal@gamil.com
}

\begin{abstract}
Sustainability of business organizations is an important issue at any point of time in society and needs different types of behavioural attributes to be followed by managers and the employees to be followed to satisfy or to make an impact on stakeholders. The management thinkers of many schools of thought suggest to find out optimum behaviour to ensure success. It is observed that some Animals in their living style adopt certain behaviour which is in built in their way of survival. The principles behind their living methods have several managerial implications. This paper is based on the living behaviour of animals and the managerial lessons involved in it which are relevant to Business Managers in their business operations.
\end{abstract}

Keywords: Management lessons, Resilience development, Learning from animals, Learning from reflections.

\section{INTRODUCTION :}

Learning makes the man better and improves his style of functioning and performance. Continuity in the learning process keeps a man fit in a changing environment. He can exhibit his good qualities and can act as a role model to others in his learning process. A learner cannot only improve himself but also facilitate others to improve their learning in a community. The general perception is that real learning happens at school. A person achieves his learning progression at different levels viz primary, secondary, higher secondary and at undergraduation and post-graduation levels. Teacher plays a key role in shaping the career progression of a student. Teachers at different levels act as mentors, guides, and facilitators of the learning process. However, it is the known fact that the learning process has different dimensions. Apart from classroom teaching learning environment, a student can equip himself better through reading, interaction with others, observation of others performances, associations with learned people and his own reflections. A student keeps himself open to all this avenue can shape himself better and lay a solid foundation to build up his career.

Observation of nature provides learning opportunities for the students and the purpose of this paper is to provide learning avenues to students especially management students from observing the animals and their living behaviour. Animals follow their own discipline to survive in an open environment. The basic input is taken from Chanakya Neeti Darpana for further elaboration of the paper [1-2]. As per Chanakya's view, there is one learning lesson each from lion and crane, the living style of cock provides four lessons, crow provides five lessons, dog provides six lessons, and donkey provides three lessons. "Simhad Eakam, Bakad Eakam, Shiksha Chatvari Kakkutat Vayasat, Pancha Shikshechha, Shat Sunah Thrinee Gardabaha”.

\section{OBJECTIVES \& METHODOLOGY :}

The very objective of the paper is to draw managerial lessons from the living style of animals such as lion, crane, dog, crow, cock, and 
donkey. The living behaviour of animals has been taken from Chankey Neethi Darpana written by a well-known expert who wrote famous "Artha Shastra" in about 3000 BC which provides lessons to govern the country in a systematic way. The principles adopted by animals have been highlighted in the paper which is relevant to Business Managers in the present context. Many management thinkers also studied animal and bird's behaviour and their implications for management and leadership behaviour [3-9].

\section{LESSON FROM LION :}

Lion is called the king of the forest. Before executing its work, lion plans properly with adequate care. Once the planning is done it executes with full focus and by synergising its efforts. It won't relax until the work is over. A manager who is in the helm of affairs of business projects needs to understand the concept of planning with care and execution of the project with full thrust. Most of the failures in business happen either due to lack of adequate planning and preparation or execution of the project with wholehearted efforts. The success in business comes to those who dare and act. It seldom comes to timid. Therefore, business managers before venturing into any new projects or business activity need to equip themselves fully with facts and figures, proper analysis of the market condition, and execute the project putting wholehearted efforts. Anything done in a hurry or done without a proper understanding of the market environment may not fetch expected results. The concept of concern and care is very much essential to drive the project in the path of success.

\section{LESSON FROM CRANE :}

Crane when it sights an object like fish, concentrate along with regulating the body and wait for the right time with patience. At right time it catches the object with the right force. Before striking its object, crane calculates the right distance and force required to complete the task. Self-awareness, self-regulation, selfmotivation and action at the right time with the right force are the lessons a business manager can learn from the way of living of crane.
A manager needs to focus his attention on the task along with awareness of his strengths and limitations. He needs to evaluate the risk involved, maintain professionalism and take decision at the right time with the right effort. Right decision at right time fetches desirable results. Undivided attention on the problem allows a manager to understand it better and enable him to solve it in a proper way.

\section{LESSON FROM COCK :}

The cock imparts four lessons viz. Early rising, keep ready for self-protection or attacking, allow others to take their due share, and grab its legitimate share. In the early morning, it is a cock which gives the wake-up call. Early rising provides flexibility in time so that there will not be any hurry or tension in the day's activity. Time management is very much essential for business managers. This not only shows selfdiscipline but also enables one to do the duty without much stress or tension. Work without much stress enables a business manager to take planned decisions systematically. His style of functioning can be an example to others for better management.

The second lesson from cock is to keep yourself ready to face challenges. It may be selfprotection or exhibit required aggression for survival. Keep oneself fit in the changing environment is the need of the hour for business managers.

The third lesson is giving the due share to others. Cock allows others to take their share without any constraints. This quality is essential for managers in employee relationships and employee treatment. Business managers from the point of view of business development need to take care of their employees with an attractive incentive package. Then only they can build the team and lay a solid foundation for business.

The fourth lesson is grabbing its own share. What is the legitimate share should be identified and has to be claimed without any hesitation. A business manager should not have any inhibitions to claim its right remuneration and incentives appropriate to his efforts and risk involvement. 


\section{LESSON FROM CROW :}

The lessons from crow are - to be alert and watchful, collect the desirable things for later use, make love in privacy, don't get scared away easily, and don't trust anyone fully.

Alertness and watchfulness are necessary for managers to monitor the business process in the formal framework. It helps to overcome the internal limitations and identify the poor performers. Watchfulness also helps to avoid failures and internal sluggishness.

Resource conservation is required for a business to maintain steadiness in business operations. It enables Business Managers to maintain resilience during the depression and unfavourable situations.

Love is a personal matter which has to be done in privacy to maintain one's dignity and selfrespect. Creation of a scene in public brings down the image both of the individual and also the business organisation. From the point of view of the image of the organisation, business leaders need to keep themselves away from scandals and licentious behaviour.

Running a business calls for adequate courage and confidence. If a manager is weak minded, he cannot exhibit his stability and gain employee confidence in the organisations.

Trusting fully or dependent on another person in total may create problematic situations. Watching and testing is a strategic option a business manager needs to maintain to safeguard his business activity. A person may command terms or deceive the organisation if the organisation is dependent on him fully.

\section{LESSON FROM DOG :}

Loyalty to the master, contended sleep, ready to wake up even for a slight noise, fight ferociously without any shy, eat adequate food when available, not worried if sufficient food is not available are the six qualities of a dog.

These qualities provide guiding principles to a business manager. He needs to exhibit his concern and care with at most loyalty to his organisation. He has to keep himself ready for any tuff work related to his organisation. $\mathrm{He}$ needs to have full satisfaction for whatsoever he is getting and has to grab the opportunity for his benefit when available to him. Dissatisfaction or disappointment is common in any work environment. If one is worried too much about this, he cannot put effort for future endeavours. What had happened in the past should not be kept in mind throughout. This constraint his future progress.

\section{LESSON FROM DONKEY :}

Donkey's living behaviour provides three lessons, never refuse to work, have contentedness and society. Donkey works in cold or hot environment. It does tiresome work without complaints and it keeps cool and contended. A business manager has to maintain balance during tuff times as well as a good time. He should know how to manage disappointment and maintain continuity of the business.

\section{MANAGERIAL IMPLICATIONS \& SUGGESTIONS :}

The role of business managers is to make proper decisions for the survival and growth of a business organisation. Proper planning and coordination, motivation and control are necessary to keep up the fitness of the organisation. While taking decisions business managers have to evaluate each and every option for the optimal solution. The lessons from the life behaviour of animals would help the business manager to take the right decisions at the right time.

Wholehearted efforts with proper planning full attention at work, exploitation of right opportunity, develop the team spirit, assertiveness, balancing the good and bad situations, self-awareness, self-regulation, selfmotivation, time planning, good relationship, employee care, and concern would help business managers to drive the business towards better heights. Table 1 depicts the summary of the animal and bird's behaviour and their managerial implications. 
Table 1 : Managerial implications of animal behaviours

\begin{tabular}{|c|c|c|c|}
\hline S. No. & Animal & Typical Behavior & Managerial Implications \\
\hline 1 & Lion & $\begin{array}{l}\text { Planning properly with adequate } \\
\text { care }\end{array}$ & $\begin{array}{l}\text { Planning with care and execution of } \\
\text { the project with full thrust }\end{array}$ \\
\hline 2 & Crane & $\begin{array}{l}\text { Concentrate along with regulating } \\
\text { the body and wait for the right time } \\
\text { with patience. }\end{array}$ & $\begin{array}{l}\text { Self-awareness, self-regulation, self- } \\
\text { motivation and action at right time } \\
\text { with the right force }\end{array}$ \\
\hline 3 & Cock & $\begin{array}{l}\text { (1) Early rising, } \\
\text { (2) Keep ready for self-protection } \\
\text { or attacking, } \\
\text { (3) Allow others to take their due } \\
\text { share, } \\
\text { (4) Grab its legitimate share. }\end{array}$ & $\begin{array}{l}\text { (1) Time management } \\
\text { (2) Self-protection or exhibit } \\
\text { required aggression for survival. } \\
\text { (3) Justice to employees without } \\
\text { greediness } \\
\text { (4) Should not have any inhibitions } \\
\text { to claim the right remuneration and } \\
\text { incentives appropriate to his efforts } \\
\text { and risk involvement. }\end{array}$ \\
\hline 4 & Crow & $\begin{array}{l}\text { (1) Always to be alert and watchful, } \\
\text { (2) Collect the desirable things for } \\
\text { later use, } \\
\text { (3) Make love in privacy, } \\
\text { don't get scared away easily, } \\
\text { (4) Don't trust anyone fully. }\end{array}$ & $\begin{array}{l}\text { (1) Alertness and watchfulness while } \\
\text { monitoring business processes } \\
\text { (2) Resource conservation is } \\
\text { essential for a business to maintain } \\
\text { steadiness in business operations } \\
\text { (3) Business leaders have to keep } \\
\text { themselves away from scandals and } \\
\text { licentious behaviour. } \\
\text { (4) Running a business requires } \\
\text { adequate courage and confidence. } \\
\text { Trusting fully or dependent on } \\
\text { another person may create a } \\
\text { problematic situation. }\end{array}$ \\
\hline 5 & Dog & $\begin{array}{l}\text { (1) Loyalty to the master, } \\
\text { (2) Contended sleep, } \\
\text { (3) Ready to wake up even for a } \\
\text { slight noise, } \\
\text { (4) Ferociously fighting without } \\
\text { any shy, } \\
\text { (5) Eat adequate food when } \\
\text { available, } \\
\text { (6) Not worried if sufficient food is } \\
\text { not available }\end{array}$ & $\begin{array}{l}\text { (1) Manager has to exhibit his } \\
\text { concern and care with at most } \\
\text { loyalty to his organisation. } \\
\text { (2) He has to role model and keeps } \\
\text { himself ready for any tuff work } \\
\text { related to his organisation. } \\
\text { (3) He needs to have full satisfaction } \\
\text { for whatsoever he is getting and has } \\
\text { to grab the opportunity for his } \\
\text { benefit when available to him. } \\
\text { (4) He should know that satisfaction } \\
\text { or disappointment is common in any } \\
\text { work environment. }\end{array}$ \\
\hline 6 & Donkey & $\begin{array}{l}\text { (1) Never refuse to work, } \\
\text { (2) Have contentedness to master } \\
\text { (3) Have contentedness to society }\end{array}$ & $\begin{array}{l}\text { (1) A business manager has to } \\
\text { maintain balance during tuff times as } \\
\text { well as good time. } \\
\text { (2) Know how to manage } \\
\text { disappointment and maintain } \\
\text { continuity of the business. }\end{array}$ \\
\hline
\end{tabular}




\section{CONCLUSION :}

A business manager would enable to enroot the business in the path of success by incorporating the above-mentioned lessons which he can learn from the living behaviour of animals. This approach enables him to strengthen the business and also shows others the proper way in business survival and growth.

\section{REFERENCES :}

[1] Suhas B.R. (2011). Chanakya Nithi Darpana, Sadhana Publishers, Bangalore.

[2] Olivelle, P. (Ed.). (2009). Pañcatantra: The Book of India's Folk Wisdom. Oxford University Press.

[3] McKillop, I. G., \& Sibly, R. M. (1988). Animal behaviour at electric fences and the implications for management. Mammal Review, 18(2), 91-103.

[4] Provenza, F. D., \& Balph, D. F. (1987). Diet learning by domestic ruminants: theory, evidence, and practical implications. Applied Animal Behaviour Science, 18(3-4), 211-232.

[5] McLean, I. G., Hölzer, C., \& Studholme, B. J. (1999). Teaching predator-recognition to a naive bird: implications for management. Biological Conservation, 87(1), 123-130.

[6] Robertson, C. P., Baker, P. J., \& Harris, S. (2000). Ranging behaviour of juvenile red foxes and its implications for management. Acta Theriologica, 45(4), 525536.

[7] Barry, A. L. (2016). Lessons from Animals, Real and Imaginary, in the Work of Theodor Geisel. The Educational Significance of Human and Non-Human Animal Interactions (pp. 117-131). Palgrave Macmillan, New York.

[8] Kurtz, P. M. (2018). Of Lions, Arabs \& Israelites: Some Lessons from the Samson Story for Writing the History of Biblical Scholarship. Journal of the Bible and its Reception, 5(1), 31-48.
[9] Mills, D. S., McDonnell, S. M., \& McDonnell, S. (Eds.). (2005). The domestic horse: the origins, development and management of its behaviour. Cambridge University Press.

$* * * * * *$ 